\title{
FACTORS AFFECTING CAPITAL STRUCTURE CHOICE: NEW EVIDENCE FROM TURKISH NON-FINANCIAL LISTED COMPANIES
}

\author{
DOI: 10.17261/Pressacademia.2019.1015 \\ JBEF- V.8-ISS.1-2018(5)-p.53-70

\section{Eyup Basti ${ }^{1}$, Nizamettin Bayyurt ${ }^{2}$} \\ ${ }^{1}$ University of Metropolitan Tirana, Tirana, Albenia. \\ eyupbasti@umt.edu.al, ORCID:_0000-0003-2280-4221 \\ ${ }^{2}$ Istanbul Technical University, Istanbul, Turkey. \\ bayyurt@itu.edu.tr, ORCID: 0000-0001-6993-4715
}

To cite this document

Basti, E., Bayyurt, N. (2019). Factors affecting capital structure choice: new evidence from Turkish non-financial listed companies. Journal of Business, Economics and Finance (JBEF), V.8(1), p.53-70.

Permemant link to this document: $\underline{\text { http://doi.org/10.17261/Pressacademia.2019.1015 }}$

Copyright: Published by PressAcademia and limited licenced re-use rights only.

\begin{abstract}
Purpose - Factors affecting capital structure choices of Turkish non-financial listed companies are tested in this study. We investigate the relation between firm leverage and firm level variables, expected inflation and GDP growth rates.

Methodology - We used annual data of exchange listed non-financial corporations in addition to expected inflation and GDP growth rates. We applied panel regression models to our panel data set of 292 firms.

Findings - We found four factors, i.e. profitability, growth (MVA/BVA), tangibility and industry median leverage are effective in explaining capital structures of Turkish listed firms. While profitability and growth have signs in line with the prediction of the pecking order theory, signs of tangibility and industry median leverage favor the trade off theory. We also divided our sample into clusters based on firm size and $2000-2001$ financial crisis and repeated the analysis.

Conclusion- Results of this analysis suggest that trade off theory explains better the financing behavior of large-sized firms. Pecking order theory seems to better account for financing behaviors of Turkish firms before 2002; and trade off theory seems to explain better their capital structure choices after the $2000-2001$ financial crisis.
\end{abstract}

Keywords: Trade off theory, pecking order theory, firm leverage, non-financial firms, Turkey. JEL Classification: C33, G32, G00

\section{INTRODUCTION}

Factors behind capital structure choices of companies have been investigated intensively since the seminal paper of Modigliani and Miller in 1958. Several theories have been proposed to account for the capital structure decisions of corporations. Trade off and pecking order theories are the most widely cited capital structure theories. Trade off theory argues that firms determine their capital structures at a point where tax shield benefits of additional debt and expected financial distress and bankruptcy costs are in equilibrium. Pecking order theory, which rests upon the asymmetric information hypothesis, asserts that firms prefer internally generated funds over external funds, issue debt first if external funds are necessary, and issue equity only as a last resort. This pecking order arises since issuing equity is viewed by outside investors as a pessimistic signal about the company's value. 
These theories have been tested from many aspects in the literature. Relations between leverage and independent variables such as tangibility of assets, uniqueness of assets, marginal tax rates, taxable income, profits, firm size, firm growth, non-debt tax shields, volatility of earnings, industry median leverage, R\&D, and advertising expenditures have been investigated in many studies. Although there is fair consensus about the factors affecting capital structure of firms, yet there isn't a single theory that can explain the motivations behind the capital structure decisions of corporations. Myers (2001) attributes this outcome to the conditionality of capital structure theories.

This study aims to contribute to the capital structure literature by utilizing firm level and macroeconomic data within the context of a developing country, Turkey. We investigate the role of firm specific factors and macroeconomic measures on the capital structure of listed non-financial Turkish firms. In other words, we estimate the relation between a firm's debt ratio and (1) firm-specific variables and (2) two macroeconomic measures. Our results are consistent with some elements of both the pecking order theory and the trade off theory of capital structure. Evolution of capital structure theories, literature review and analysis variables are provided in the second section. The third section includes data description, specifies the analysis method and provides analysis results. A fourth section summarizes the conclusions reached in the study.

\section{CAPITAL STRUCTURE THEORIES AND ANALYSIS VARIABLES}

\subsection{Capital Structure Theories}

Capital structure choice of firms is one of the most important issues in the corporate finance literature. Before 1958, the traditional approach was the predominant capital structure theory. The traditional approach asserts that there is an optimal capital structure of debt and equity which minimizes weighted average cost of capital and therefore maximizes firm value. This process is described as follows: As debt is a cheaper source, by increasing its weight, it is possible to decrease the weighted average cost of capital. Discounting expected future cash flows to debt and equity holders, by a lower weighted average cost of capital, increases firm value.

In 1958, Franco Modigliani and Merton Miller (hereafter MM) showed quantitatively that a firm's value is independent of its capital structure, in a world where there is no market imperfections like taxes and transaction costs. They showed that a firm's value is not affected by how it was financed; instead a firm's value is determined by the present value of the expected future cash flows that will be generated by its productive assets.

Since other researchers argued that firms pay taxes, MM revised their theory by adding taxes. In their second article, MM proposed that, as interest charges of debt are tax deductible and therefore provide a tax shield, leveraged firms' value must be higher than unleveraged firms' value as much as the present value of all future interest tax shields. In other words, they argued that a leveraged firm's value is equal to an identical unleveraged firm's value plus the present value of all future tax shields provided by interest of debt (Modigliani and Miller, 1963). However, this version of the MM's capital structure theory did not take into account the financial distress and bankruptcy costs caused by the heavy use of debt. Therefore, it was incomplete. These studies of MM constituted the base for the development of the modern capital structure theories, namely trade off and pecking order.

Trade off theory, derived upon the studies of MM, argues that firms determine their capital structures at a point where tax shield benefits from borrowing and costs of financial distress and bankruptcy are in equilibrium. In other words, the optimization of firms' financial structure involves a single period tradeoff between the tax advantage of debt and financial distress and bankruptcy costs (Kraus and Litzenberger, 1973). This standard version of the trade-off theory is referred to as the static trade-off theory. ${ }^{1}$ There is also dynamic trade off theory which argues that target leverage is time-varying due to the fact that firm characteristics and market conditions vary over time (Fischer et al., 1989).

The trade off theory predicts moderate indebtedness for tax-paying firms. It predicts that target debt ratios vary from firm to firm. Companies with safe, tangible assets and plenty of taxable income to be shielded should have higher target debt ratios than companies with risky, intangible assets. Unprofitable companies with risky, intangible assets must rely on equity financing (Myers, 2001).

${ }^{1}$ In this paper, trade-off theory refers to the static trade-off theory. 
Trade off theory successfully explains many industry differences in capital structure. For example, high-tech growth companies, whose assets are risky and mostly intangible, normally use little debt. Utility companies and retailers can and do borrow heavily because their assets are tangible and relatively safe. On the other hand, trade off theory cannot explain why some of the most successful companies grow with little debt. Although the trade off theory predicts that high profits should mean more debtservicing capacity and more taxable income to shield, and therefore higher debt ratios, some very successful companies operate with very low debt ratios (Myers, 2001; Brealey et al., 2009).

Pecking order theory is proposed by Myers (1984) and Myers and Majluf (1984) to explain why profitable companies borrow less. Pecking order theory rests upon the asymmetric information hypothesis which argues that managers know more than outside investors about the profitability and prospects of a firm. Thus investors may not be able to assess the true value of a new issue of securities by the firm. They may be especially reluctant to buy newly issued common stocks, because they worry that the new shares will turn out to be overpriced. Since managers know their company's prospects better than outside investors do, they will be tempted to time stock issues when their companies' stocks are overpriced. On the other hand, if managers believe that their companies' stocks are underpriced, they will not issue equity, but will issue debt. As investors know these attitudes of managers, they interpret the announcement of a stock issue as a pessimistic signal about the company's value and reduce the stock price accordingly. Because of these signals sent by common stock and debt issues to financial markets, firms use their internal funds first when they need financing. If internal funds are not adequate, firms issue debt first and issue equity only as a last resort. This pecking order arises since an issue of debt is less likely than an issue of equity to be interpreted by outside investors as a bad signal (Myers, 1984; Myers, 2001).

The pecking order theory explains why the most profitable firms generally borrow less; it is not because they have low target debt ratios - according to pecking order theory they don't have a target debt ratio - but because they don't need outside money. Less profitable firms issue debt because they do not have sufficient internal funds for their capital investments and because debt is first in the pecking order for external financing (Myers, 2001; Brealey et al., 2009).

Many studies have focused on explaining capital structure decisions of corporations since the 1960s. There are plenty of studies in favor of both theories. Causes of these conflicting results may be accounted for as follows: There might be other motivations behind capital structure choices of corporations. For example, some companies prefer high debt ratios in order to discipline managers and not to let them waste free cash flow. Mature companies that do not have profitable investment opportunities may prefer higher debt ratios in order to pass excess cash to investors. On the other hand, growth companies may choose equity financing primarily as they have too much value to lose in case of a bankruptcy (Myers, 2001). Some studies testing trade off and pecking order theories are summarized below.

Bradley et al. (1984) used cross-sectional, firm-specific data of 851 US firms and tested the trade off theory applying regression of debt ratio against three proxy variables, namely volatility of earnings, non-debt tax shields, and advertising and R\&D expenses. They found that volatility of firm earnings and the intensity of R\&D and advertising expenditures were negatively related to leverage. These results showed that firms with high probability of financial distress stand away from debt which is consistent with the implications of trade off theory. On the other hand, contrary to theory, they also detected a positive strong relation between firm leverage and the amount of non-debt tax shields.

MacKie-Mason (1990) used primary seasoned offerings data of 1,747 US companies and approached the issue from tax shield benefit point of view of debt. He tested whether firms with low marginal tax rates were more likely to issue equity compared to more profitable firms facing full statutory tax rate. He classified firms with tax loss carry-forwards as firms with low marginal tax rates. On the other hand, firms with investment tax credits were described as firms with high marginal tax rates. His results provided strong and robust evidence that the marginal tax rate does affect financing decisions. He proved that firms with high marginal tax rates issue more debt which was consistent with the trade off theory.

Korajczyk and Levy (2003) estimated the relation between firms' debt ratios and firm-specific variables and macroeconomic conditions. They used the fitted values of this relation to estimate firms' target capital structures. They then investigated the relation between security issuances/repurchases, the deviation from target leverage, and both firm-specific and macroeconomic variables. They argue that the relation between firm-specific variables and target leverage is consistent with some elements of both the pecking order theory and the trade off theory of capital structure. They found that larger firms and firms with more tangible assets have higher leverage. On the other hand, they determined that firms with unique assets and firms with large depreciation tax-shields have lower leverage. They also identified that deviations from estimated target leverage explain firms' choice of security issuance. All of these findings are consistent with the trade off theory. However, they also detected a negative 
relation between operating income and leverage and a negative relation between the macroeconomic variables and leverage, both of which are consistent with the pecking order theory.

Frank and Goyal (2009) utilized US publicly traded firm data from 1950 to 2003 andidentified six factors which are effective in explaining capital structures of firms. These factors are industry median leverage, tangibility of assets, profits, firm size, marketto-book assets ratio and expected inflation. Five of these factors were found in favor of trade off theory and one of them was in favor of pecking order theory. They argued that their empirical evidence seems consistent with the trade off theory of capital structure.

Shyam-Sunder and Myers (1999) developed a model to test pecking order theory. In their model, they described financing deficit of firms and they linked financing deficits with corporate debt. Then, they tested pecking order theory by utilizing data of 157 U.S. firms that had traded continuously over the period 1971 to 1989 . Their results showed that external funding was dominated by debt. Therefore, they concluded that they found strong support for the pecking order theory.

Frank and Goyal (2003) tested pecking order theory on a cross-section of publicly traded US firms over the period 1971-1998. Their results revealed that financing deficits are followed by equity issues more closely than by debt issues. They argued that support for the pecking order theory has been declining because of the increasing number of publicly traded small firms, which do not follow pecking order, in 1980s and 1990s and decreasing support even from large firms for pecking order theory over time.

Tong and Green (2005) tested the pecking order and trade off theories using a cross-section of the largest Chinese listed companies. They set up three models in which trade off and pecking order theories give distinctively different predictions: (1) the determinants of leverage; (2) the relationship between leverage and dividends; and (3) the determinants of corporate investment. They found a significant negative correlation between leverage and profitability in model 1; a significant positive correlation between current leverage and past dividends in model 2, both of which supported the pecking order theory over trade off theory. However, their model 3 was inconclusive. Therefore, they argued that their results provide tentative support for the pecking order theory.

Chen et al. (2013) utilized panel data of publicly-traded Taiwanese firms to test the pecking order and the market timing theories over the period 1990-2005. They indicated that net equity issues track the financing deficit much more closely than net debt issues do. As this result is just opposite of what the pecking order theory argues, their results did not support the pecking order theory.

Gönenç (2003) examined the impact of profitability, asset tangibility, size, and growth opportunities on capital structure decisions of Turkish Industrial firms by including the data of 271 companies listed on the Istanbul Stock Exchange (ISE) for the period 1990 to 1999 . His results identified a negative relation between profitability and leverage, which is consistent with the pecking order theory. On the other hand, he detected a positive relation between size, tangibility and leverage and a negative relation between growth opportunities and leverage, all of which are in favor of the trade off theory.

Sayılgan et al. (2006) analyzed the impact of firm specific characteristics on the corporate capital structure decisions of Turkish firms. They included 123 ISE listed manufacturing firms' data from 1993 to 2002 . Their results showed that there was a positive relation between size and leverage and a negative relation between growth opportunities, non-debt tax shields and leverage, which are consistent with the trade off theory. On the other hand, their results revealed a negative relation between profitability, tangibility and leverage, which are in favor of the pecking order theory.

Korkmaz et al. (2007) analyzed the factors that affect capital structures of 37 iSE listed and small and medium sized manufacturing sector companies for the period 1997 - 2004. Their results revealed a negative relation between profitability and leverage, a positive relation between business risk, non-debt tax shields and leverage. The negative relation between profitability and leverage and the positive relation between business risk and leverage are consistent with the pecking order theory.

Demirhan (2009) analyzed the factors that are effective in the formation of capital structures of the service sector companies listed on the iSE. She included 20 companies' data for the period $2003-2006$. Her results demonstrated a negative relation between profitability, growth, non-debt tax shields and leverage; a positive relation between size and leverage, all of which are consistent with the pecking order theory. Her results also revealed a negative relation between tangibility and leverage, which is in favor of trade off theory. 
Yıldız et al. (2009) tested the validity of the capital structure theories for iSE listed companies. They utilized data of 138 manufacturing companies for the period 1998 - 2006. Their results showed a negative relation between profitability and leverage and a positive relation between growth and leverage, which are consistent with the pecking order theory. They also found a positive relation between size and leverage, which is in line with the trade off theory.

Gülşen and Ülkütaş (2012) analyzed the capital structure approach taken into account by industrial firms in formation of their capital structures. They used data of 143 corporations included in iSE Small and Medium Sized Enterprises' Industrial Index for the period 1990 to 2005 . They detected a negative relation between profitability, size and leverage. Therefore, they concluded that their results were in line with the pecking order theory.

Bayrakdaroğlu et al. (2013) investigated determinants of capital structures of the Turkish listed companies. They included data of 243 ISE listed corporations for the period 2000 - 2009. They found a positive relation between size, tax rate and leverage; a negative relation between non-debt tax shields, gross domestic product (GDP) growth rate and leverage, all of which are consistent with the trade off theory. Their results also revealed a positive relation between growth opportunities and leverage; a negative relation between profitability, tangibility and leverage, all of which are in line with the pecking order theory. They argued that the pecking order theory was more successful in explaining capital structures of the Turkish listed companies than the trade off theory.

Köksal et al. (2013) investigated factors that are effective on capital structures of the Turkish non-financial firms. They utilized a large data set including both public and private companies from 1996 to 2009 which is compiled by Central Bank of the Republic of Turkey (CBRT). Their results showed that there was a negative relation between profitability and leverage, which is in accordance of the pecking order theory. They also detected a positive relation between firm size, tangibility, industry median leverage, and expected inflation and leverage; and a negative relation between business risk, GDP growth rate and leverage; all of which are in favor of the trade off theory. Based on these results, Köksal et al. (2013) concluded that the trade off theory was more successful in explaining capital structure decisions of Turkish non-financial firms than the pecking order theory.

Acaravcı (2014) investigated the determinants of capital structures of Turkish firms. She utilized data of 79 manufacturing sector firms listed on the iSE for the period 1993 to 2010. She detected a positive relation between growth opportunity and leverage. She also found a negative relation between profitability, size, tangibility and leverage, all of which are in favor of the pecking order theory.

Our study has two novelties over previous studies investigating factors affecting capital structures of Turkish firms. First, our study covers the broadest time period (1988 to 2013) among all the capital structure studies conducted on Turkish firms. Second, we included the highest number of firms' data (261) except Gönenç (2003) and Köksal et al. (2013). As Gönenç (2003) documents results from 1990 to 1999 period, our study provides findings from a more up-to-date data with a broader time span over Gönenç (2003). On the other hand, Köksal et al. (2013)'s data set has problems from two aspects: First, to our knowledge, this is the first study that investigates the factors affecting capital structures of firms by utilizing private firm data as well as public firm data. However, Myers (2001) argues that focusing on public, nonfinancial corporations with access to international capital markets is the right place to start for capital structure research. Thus, such a data set may also include data of firms that do not have access to public financial markets and there are doubts about this data set whether it is reflecting financing behaviors of unconstrained firms. Second, CBRT data are collected through questionnaires from both public and private corporations. Private companies are not required to have audited their financial statements. Therefore, reliability of this data set is low compared to published data of listed companies. Thus, since it covers the broadest time span in the literature and draws conclusions from a high number of listed firm data compiled from audited financial statements, our study is more representative of the Turkish non-financial listed corporations' sector than any other study.

\subsection{Variables}

Profitability: Trade off theory predicts a positive relation between profitability and leverage. As the probability of entering into financial distress is low for profitable firms and they have more taxable income to shield, profitable firms' debt ratio must be higher. Pecking order theory, on the other hand, estimates the reverse. Based on pecking order theory, firms try to finance investments with internal funds first. If internal funds are inadequate, they use debt financing in the second order. Therefore, pecking order theory estimates a negative relation between leverage and profitability and argues that profitable firms will be less leveraged in time because they will have more resources to invest (Titman and Wessels, 1988; De Jong et al., 2007; Frank and Goyal, 2009). Profitability is described as operating income divided by total assets. 
Tangibility of assets: Trade off theory estimates a positive relation between tangibility of assets and indebtedness. Tangible assets are easy to collateralize and, relatively speaking, they keep their values even if the firm enters into financial distress. Thus, firms with more tangible assets can borrow easily. Therefore, based on the trade off theory, a positive relation is predicted between tangibility and leverage (Myers, 2001; Myers and Read, 2012). Pecking order theory anticipates the opposite. Tangibility of assets mitigates the informational asymmetry problem and therefore it makes equity issues less costly. Thus, firms with more tangible assets are expected to have lower leverage ratios (Harris and Raviv, 1991; Frank and Goyal, 2009). Tangibility is defined as the ratio of net fixed assets to total assets.

Firm size: Trade off theory predicts a positive relation between firm size and leverage. This is because large firms' assets are more diversified and large firms have better reputation in debt markets. Pecking order theory is interpreted as anticipating a negative relation between firm size and leverage. As large firms have been in operation for longer periods and they are well known, they can issue equity less costly than small firms. In addition, large firms have the opportunity to retain earnings. Therefore, based on pecking order theory, large firms are expected to have less leverage (Tong and Green, 2005; Frank and Goyal, 2009). Logarithm of total assets is taken to represent firm size.

Growth: A high percentage of growth firms' value comes from present value of growth opportunities. In other words, most assets of growth firms are intangible. Therefore, in case of financial distress, growth firms lose much more value than nongrowth firms. Thus, trade off theory estimates a negative relation between firm growth and leverage. By contrast, pecking order theory argues that there is a positive relation between firm growth and indebtedness. This is because growth firms need more external financing and borrowing is in the first order among external financing sources. Köksal et al. (2013) and Schoubben and Van Hulle (2004) used percentage change in sales as a proxy for growth. We use market-to-book value of assets ratio (MVA/BVA) and change in logarithm of assets ( $\triangle \mathrm{LNTA}$ ) to represent growth as in Frank and Goyal (2009).

Taxes and non-debt tax shields: Trade off theory assumes that firms will increase their borrowing as their marginal corporate tax rates increase. Some studies use marginal corporate tax rate as an explanatory variable for leverage (Frank and Goyal, 2009). Corporate tax rate is not progressive in Turkey and it is fixed at $20 \%$. Therefore, we cannot use marginal tax rate as an explanatory variable for the Turkish case. Non-debt tax shields such as depreciation, R\&D and advertising expenses are also proposed in the literature as substitutes to leverage to decrease tax payments by firms (DeAngelo and Masulis, 1980; Bradley et al., 1984; Titman and Wessels, 1988; Frank and Goyal, 2009). Therefore, trade off theory predicts a negative relation between non-debt tax shields and leverage. On the other hand, since pecking order theory approaches debt financing as an external capital source rather than as a tax shield vehicle, pecking order theory does not estimate any relation between non-debt tax shields and leverage. We included depreciation over total assets as a non-debt tax shield.

Risk: Firms with more volatile operating cash flows are riskier than others. Riskier firms have higher probability of falling into financial distress and their expected financial distress costs are high. Volatile cash flows also decrease the total tax shield benefits to firms. Based on the trade off theory, high risk firms should have less debt. In other words, trade off theory predicts a negative relation between risk and leverage. Pecking order theory assumes that firms with more volatile cash flows need more external capital. Debt is of the first order among external financing sources. Thus, pecking order theory anticipates a positive relation between risk and leverage. Frank and Goyal (2009) defined risk as the variance of annual stock returns. As macroeconomic and political issues are much more effective in stock price fluctuations in Turkey, we think variance of stock returns reflects macroeconomic risks rather than firm specific risks. Therefore, we defined business risk as standard deviation of operating income over total assets over the past three years (including the current year) as in De Jong et al. (2008) and Köksal et al. (2013).

Industry median leverage: It is well known that debt ratios exhibit differences from sector to sector. These industrial differences in leverage may stem from several factors. Firstly, managers may take industry debt ratio as a benchmark and they may even use industry debt ratios as their target debt ratios. Secondly, firms in the same industry face similar economic conditions. In other words, industrial differences in technology, competition, asset types, asymmetric information level and risk may cause firms of the same industry to have similar debt ratios (Frydenberg, 2004: 8). Bradley et al. (1984) found significant differences in capital structures of firms in different sectors. Trade off theory predicts a positive relation between industry median leverage and firm leveragesince firms in the same industry face many common forces. Pecking order theory, on the other hand, anticipates a rather indirect link between industry median leverage and firm leverage since the industry should only matter to the degree that it serves as a proxy for the firm's financing deficit (Frank and Goyal, 2009). We include industry median leverage as an explanatory variable. 
Expected inflation: If expected inflation for future periods is higher than the current inflation rate, firms tend to issue more debt because higher expected inflation lowers the real cost of debt. In other words, since higher expected inflation increases future nominal interest rates, the present value of long term debts will be lower to firms. Trade off theory predicts a positive relation between expected inflation and leverage (Frank and Goyal, 2007). On the other hand, pecking order theory doesn't specify any relation between expected inflation and leverage. Expected inflation is taken as an explanatory variable for firm leverage.

Gross Domestic Product (GDP) growth rate: Economic growth positively affects most firms since firms' stock prices go up, expected bankruptcy costs go down, sales and taxable income goes up and cash increases during expansion periods. Collateral values of assets also increase during economic growth episodes. Therefore, according to trade off theory, firms are expected to borrow more during expansion periods because of the increased taxable income to shield and the high collateral value of assets. Thus, trade off theory anticipates a positive relation between GDP growth rate and leverage. By contrast, pecking order theory predicts a negative relation between GDP growth rate and leverage because firms have plenty of internal funds to invest during expansion periods and therefore they don't need external capital (Frank and Goyal, 2009). Real GDP growth rate is included as an explanatory variable.

\section{DATA, METHODOLOGY AND RESULTS}

\subsection{Data and Model Specification}

In this study, factors behind capital structure choices of Turkish listed non-financial companies are analyzed. More clearly, we investigate the relation between profitability, tangibility of assets, firm size, growth (MVA/BVA and $\triangle$ LNTA), non-debt tax shields, risk, industry median leverage, expected inflation and gross domestic product (GDP) growth rates and firm leverage. We used annual data of exchange listed non-financial corporations in addition to expected inflation and GDP growth rates. The data set for the selected firms were obtained from Finnet Limited Company, a financial data dissemination firm to both investors and researchers. The firms with missing data are excluded. The data set consists of yearly observations of 261 firms for the period 1988 - 2013. GDP growth rates are taken from World Bank database. CBRT has been disseminating expected inflation data since August 2001. Therefore, expected consumer price index (CPI) annual inflation data are taken from the CBRT data base for the 2001 to 2013 period. We took actual consumer price index inflation as a proxy for the previous years' expected inflation for the period 1988 to 2000. These actual CPI inflation data are taken from the Turkish Statistical Institute (Turkish Statistical Institute Website).

The dependent variable in our study is leverage. We included 3 different versions of leverage, namely short term debt to total assets ratio (STDTA), long term debt to total assets ratio (LTDTA) and total debt to total assets ratio (TDTA). The independent variables that are expected to have a relation with debt ratios are carefully chosen based on the previous literature. The independent variables in our estimation are profitability, tangibility, size, two measures of growth (MVA/BVA and $\triangle$ LNTA), nondebt tax shields, risk, industry median leverage, inflation, and GDP growth rate.

Table 1 provides formulas of dependent and independent variables as well as predictions of trade off and pecking order theories about the direction of association between leverage and independent variables.

\subsection{Descriptive Statistics}

Descriptive statistics for variables are presented in Table 2. The number of firms included in the analysis is 261 for the period from 1988 to 2013 with an unbalanced data set. The average short-term debt ratio is almost two times the average long-term debt ratio. This attribute shows the negative effect of the high (double digit) inflationary period on long-term borrowing ability of firms that lasted until 2004. The median leverage is below the mean leverage for all three measures of leverage. There is a large cross-sectional difference so that the minimum total debt ratio is 0 while the maximum total debt ratio is 7.24 . Minimum and maximum short-term debt ranges are also the same for the total debt range, meaning that the firm with the highest shortterm debt hasn't any long term debt. Moreover, the market value to book value of assets ratio has the highest standard deviation.

The correlation results for variables are given in Table 3 . Significant correlations at the $5 \%$ level were signed in the table. There is a negative and significant correlation between profitability and all measures of leverage, i.e. short-term, long-term and total debt ratios. A negative and significant correlation is found between tangibility and short-term leverage, but a positive and significant correlation is found between tangibility and long-term leverage, which means that firms with more tangible assets can and do borrow on a long-term basis by pledging their tangible assets instead of short-term. There is a positive and significant correlation between size and both long-term and total leverage, which shows that big companies can borrow on long- 
term. A negative and significant correlation exists between growth ( $\Delta$ LNTA)and all leverage measures, which indicates that growing companies borrow less. There is a negative and significant correlation between business risk and long-term leverage. A negative and significant relation is found between expected inflation and long-term and total leverage. There is a negative and significant correlation between GDP growth rate and short-term and total leverage. A positive and significant correlation is found between all measures of industry median leverage and all measures of leverage. There is no significant correlation between non-debt tax shield and leverage.

Moreover, there is no significant correlation between market value of assets to book value of assets and leverage.

In connection with discussions in the previous section, we propose an estimation model for leverage as follows, where the selected variables are expected to have a relation with the debt ratio:

$\mathrm{L}_{\mathrm{it}}=\alpha_{0}+\sum_{\mathrm{k}} \beta_{\mathrm{k}} \mathrm{X}_{\mathrm{kit}}+\mu_{\mathrm{i}}+\mathrm{u}_{\mathrm{it}}$

Where $\mathrm{L}_{\text {it }}$ is one of the three debt measures (short-term debt $=$ STDTA, long-term debt $=$ LTDTA or total debt $=$ TDTA) of firm $\mathrm{i}$ in year $\mathrm{t}$; $\mathrm{X}$ is the vector of the leverage factors (profitability, tangibility, size, two measures of growth, non-debt tax shields, risk, inflation, GDP growth rate and industry median leverage); $\mu_{\mathrm{i}}$ are the time-invariant unobservable firm-specific effects; and $\mathrm{u}_{\mathrm{it}}$ is the error term.

Table 1: Variable Definitions and Hypotheses

\begin{tabular}{|c|c|c|c|}
\hline Debt Ratios & Definition & $\begin{array}{l}\text { Pecking } \\
\text { Order }\end{array}$ & $\begin{array}{l}\text { Trade } \\
\text { off }\end{array}$ \\
\hline Short-term Leverage & Short-term Debt / Total Assets (STDTA) & N/A & N/A \\
\hline Long-term Leverage & Long-term Debt / Total Assets (LTDTA) & N/A & N/A \\
\hline Total Leverage & Total Debt / Total Assets (TDTA) & N/A & N/A \\
\hline \multicolumn{4}{|l|}{ Explanatory Variables } \\
\hline Profitability & Net Operating Profit / Total Assets (NOP/TA) & - & + \\
\hline Tangibility & Net Fixed Assets / Total Assets (NFA/TA) & - & + \\
\hline Size & Natural Logarithm of Total Assets (LnTA) & - & + \\
\hline Growth1 & Change in Natural Logarithm of Total Assets ( $\triangle$ LnTA) & + & - \\
\hline Growth2 & Market Value of Assets / Book Value of Assets (MVA/BVA) & + & - \\
\hline Non-debt Tax Shields & Depreciation / Total Assets (Dep/TA) & ? & - \\
\hline Risk & $\begin{array}{l}\text { Standard Deviation of Net Operating Profit / Total Assets } \\
\text { ( } \sigma \text { NOP/TA) }\end{array}$ & + & - \\
\hline Expected Inflation & Annual Consumer Price Index Expected Inflation (Explnf) & $?$ & + \\
\hline GDP Growth Rate & Percentage Change in Real GDP (GDPGr) & - & + \\
\hline $\begin{array}{l}\text { Industry Median Short- } \\
\text { term Leverage }\end{array}$ & Industry Median Short-term Debt / Total Assets (IndMedSTDTA) & ? & + \\
\hline $\begin{array}{l}\text { Industry Median Long- } \\
\text { term Leverage }\end{array}$ & Industry Median Long-term Debt / Total Assets (IndMedLTDTA) & $?$ & + \\
\hline
\end{tabular}


STDTAit is the ratio of short-term debt tototal assets of firm $i$ at time $t$, profitability is net operating profit over total assets (NOP/TA), tangibility is net fixed assets to total assets (NFA/TA), size is the logarithm of total assets (LNTA), one of the two growth measures is the change in logarithm of total assets ( $\triangle$ LNTA), the other growth measure is market value of assets over book value of assets (MVA/BVA), depreciation over total assets is taken as non-debt tax shield (Dep/TA), risk is taken as the standard deviation of net operating profit to total assets in the last three years (including current year; $\sigma N O P / T A$ ), expected annual CPI inflation is taken as expected inflation (Explnf), GDP growth rate is the annual percentage change in real GDP of Turkey (GDPGr), and the three industry median leverage measures are the median leverage of short term-debt to total assets, long-term debt to total assets and total debt to total assets (IndMedSTDTA, IndMedLTDTA, IndMedTDTA) for 3 leverage equations, respectively. We estimate the above equations using standard errors that are robust to heteroskedasticity and serial correlation.

Table 2: Descriptive Statistics of Variables in the Study

\begin{tabular}{llllll} 
Variable & Obs & Mean & Std. Dev. & Min & Max \\
\hline STDTA & 4022 & 0.1424 & 0.2363 & 0.0000 & 7.2370 \\
LTDTA & 4022 & 0.0847 & 0.1644 & 0.0000 & 2.7241 \\
TDTA & 4022 & 0.2271 & 0.3055 & 0.0000 & 7.2370 \\
NOPTA & 4022 & 0.0939 & 0.1384 & -1.0596 & 0.9096 \\
NFATA & 4022 & 0.3465 & 0.2064 & 0.0000 & 0.9869 \\
LnTA & 4022 & 17.6563 & 2.6005 & 9.0058 & 23.9580 \\
DLnTA & 3972 & 0.3079 & 0.3516 & -1.2455 & 3.2622 \\
DepTA & 4022 & 0.0457 & 0.2755 & -0.0121 & 12.0069 \\
SDNOPTA & 3513 & 0.0568 & 0.0527 & 0.0004 & 0.6528 \\
ExpInf & 4022 & 31.9521 & 32.7631 & 5.8300 & 125.5000 \\
GDPGr & 4022 & 4.1771 & 4.5926 & -5.7000 & 9.4000 \\
MVABVA & 4022 & 2.5989 & 80.1736 & 0.0003 & 5084.7050 \\
IndMedTDTA & 4022 & 0.1700 & 0.0549 & 0.0541 & 0.4210 \\
IndMedSTDTA & 4022 & 0.0909 & 0.0392 & 0.0080 & 0.1762 \\
IndMedLTDTA & 4022 & 0.0235 & 0.0174 & 0.0000 & 0.1119 \\
\hline
\end{tabular}

The panel data estimation is employed in the study to capture the dynamic behavior of the parametersand to provide more efficient estimation and information of the parameters. The ordinary least square method can provide consistent and efficient estimates of $\alpha$ and $\beta$. In practice, the advantage of panel data is that they allow us to test some of the assumptions and allow for greater flexibility in modeling differences in behavior across firms (Ho. C. H, 2004). The panel data model includes three different methods: (a) Common constant, (b) Fixed effects, and (c) Random effects. The Common constant method (also called pooled OLS method) of estimation presents results under the principal assumption that there are no differences among the data matrices of the cross sectional dimension $(\mathrm{N})$. In other words, the model estimates a Common constant for all Cross-sections (Common constant for firms). Practically, the Common constant method implies that there are no differences between the estimated cross-sections and it is useful under the hypothesis that the data set is a priori homogeneous. However, this case is quite restrictive and a case of more interest involves the inclusion of Fixed and Random effects in the method of estimation (Asterious, 2006). The Fixed effects method treats the constant as group specific, i.e. it allows for different constants for each group. The Fixed effects, also called the Least Squares Dummy Variables (LSDV) estimators, because it allows for different constants for each group and it includes a dummy variable for each group. The Random effects method is an alternative method of estimation which handles the constants for each section as random parameters rather than fixed. One obvious disadvantage of the Random effects approach is that one needs to make specific assumptions about the distribution of the random component. Also, if the unobserved group-specific effects are correlated with the explanatory variable, then the estimates will 
be biased and inconsistent. Thus the use of the Random effects method in the estimation requires a lot of care and must be employed only if it is necessary and meaningful in comparison to the Fixed effects method. Generally in the panel data analysis, the Fixed effects model assumes that each firm differs in its intercept term, whereas the Random effects model assumes that each firm differs in its error term. In this study we apply the Fixed effect method.

Table 3: Correlation of Variables in the Study

\begin{tabular}{|c|c|c|c|c|c|c|c|c|c|c|c|c|c|c|c|}
\hline & TDTA & STDTA & LTDTA & NOPTA & NFATA & LNTA & $\triangle \mathrm{LNTA}$ & DepTA & SDNOPTA & Explnf & GDPGr & MVABVA & $\begin{array}{l}\text { IndMed } \\
\text { TDTA }\end{array}$ & $\begin{array}{l}\text { IndMed } \\
\text { STDTA }\end{array}$ & $\begin{array}{l}\text { IndMed } \\
\text { LTDTA }\end{array}$ \\
\hline TDTA & 1 & & & & & & & & & & & & & & \\
\hline STDTA & $0.8460 *$ & 1 & & & & & & & & & & & & & \\
\hline LTDTA & $0.6423^{*}$ & $0.1348^{*}$ & 1 & & & & & & & & & & & & \\
\hline NOPTA & $-0.1549^{*}$ & $-0.0976^{*}$ & $-0.1475^{*}$ & 1 & & & & & & & & & & & \\
\hline NFATA & 0.0250 & $-0.0715^{*}$ & $0.1493^{*}$ & $-0.2176^{*}$ & 1 & & & & & & & & & & \\
\hline LNTA & $0.0536^{*}$ & -0.0212 & $0.1301 *$ & $-0.2930 *$ & $0.0673 *$ & 1 & & & & & & & & & \\
\hline$\Delta \mathrm{LNTA}$ & $-0.0845^{*}$ & $-0.0638^{*}$ & $-0.0656^{*}$ & $0.4048 *$ & $-0.0582 *$ & $-0.3554^{*}$ & 1 & & & & & & & & \\
\hline DepTA & 0.0092 & 0.0162 & -0.0063 & $-0.0331^{*}$ & $0.0404^{*}$ & $0.0434^{*}$ & -0.0065 & 1 & & & & & & & \\
\hline SDNOPTA & $0.0398 *$ & $0.0667^{*}$ & -0.0220 & $0.2894^{*}$ & $-0.1583^{*}$ & $-0.3595^{*}$ & $0.1214^{*}$ & -0.0174 & 1 & & & & & & \\
\hline Explnf & $-0.0477^{*}$ & -0.0013 & $-0.0868 *$ & $0.4601^{*}$ & $-0.0588^{*}$ & $-0.7105^{*}$ & $0.5608^{*}$ & $-0.0397^{*}$ & $0.2996^{*}$ & 1 & & & & & \\
\hline GDPGr & $-0.0558^{*}$ & $-0.0692^{*}$ & -0.0043 & $-0.0319^{*}$ & $0.0409^{*}$ & $0.0478^{*}$ & -0.0213 & -0.0006 & $-0.0709 *$ & $-0.037^{*}$ & 1 & & & & \\
\hline MVABVA & -0.0101 & -0.0076 & -0.0079 & -0.0077 & -0.0286 & 0.0084 & -0.0143 & -0.0007 & $0.1598^{*}$ & -0.0102 & -0.0298 & 1 & & & \\
\hline IndMedTDTA & 0.1519* & $0.1712 *$ & $0.0362 *$ & $-0.0382^{*}$ & -0.0147 & $0.0752^{*}$ & $-0.0722^{*}$ & 0.0312 & $-0.0665^{*}$ & -0.0239 & $-0.3455^{*}$ & 0.0092 & 1 & & \\
\hline IndMedSTDTA & $0.1352 *$ & $0.1730 *$ & 0.0025 & -0.0020 & -0.0245 & 0.0235 & 0.0007 & 0.0267 & $-0.0381 *$ & 0.0799* & $-0.3913^{*}$ & 0.0035 & $0.9054 *$ & 1 & \\
\hline IndMedLTDTA & 0.0583* & 0.0303 & $0.0649 *$ & $-0.0552^{*}$ & -0.0083 & 0.0121 & $-0.2934 *$ & $-0.0365 *$ & $-0.1551^{*}$ & $-0.2308^{*}$ & -0.0157 & 0.0122 & $0.3983^{*}$ & $0.1904^{*}$ & 1 \\
\hline
\end{tabular}

* denote significance at 5 percent level

\section{EMPIRICAL RESULTS}

We estimate panel data analysis by the Fixed effects method for the selected study period for short-term debt (STDTA), longterm debt (LTDTA) and total debt (TDTA) ratios. The robustness of parameter coefficients are used to explain the relationship between debt ratios and the selected independent variables. The estimation results are given in Table 4 . We summarize and interpret these results in light of the theory and the previous findings as follows:

Profitability is negatively and significantly associated with all three leverage ratios at 1 percent level, which shows that firms with more profits borrow less. This result is in line with the empirical evidence found in almost all of the previous studies, such as, among others, Korajczyk and Levy (2003), Tong and Green (2005) and Köksal et al. (2013). One of the growth measures, namely market value to book value of assets (MVA/BVA), has a positive and significant relation with both short-term leverage and total leverage ratios at 1 percent level, which suggests that growing firms had to use more short-term debt in their capital structures especially because of the high inflation in Turkey during the analysis period. This finding is parallel to the results of Yıldız et al. (2009) and Bayrakdaroğlu et al. (2013). These findings on profitability and growth are consistent with the prediction of the pecking order theory.

There is a positive and significant association between industry median leverage and short-term and total leverage measures at the 1 percent level, which means that firms try to approximate their debt ratios to their sector's median leverage. This finding on industry median leverage is consistent with the empirical evidence found in Frank and Goyal (2009) and Köksal et al. (2013). Tangibility has a positive and significant relation with long-term leverage at the 1 percent level and total indebtedness at the 5 percent level. This outcome indicates that firms with more tangible assets can pledge these tangible assets and borrow in longterm rather than short-term. Gönenç (2003), Frank and Goyal (2009) and Köksal et al. (2013) also found a positive association between tangibility and leverage. These results on industry median leverage and tangibility are in favor of the trade off theory. 
Our analysis results also revealed that there is no significant relationship between other variables; namely size, growth ( $\triangle L N T A)$, non-debt tax shields, risk, expected inflation and GDP growth rate, and all three leverage measures.

A robustness check to validate the above results is presented in this part. We divide the firms into three equal clusters by value of total assets and run the fixed effects model for two different groups which contain the smallest and largest firms. Table 5 presents the results of the analysis done for STDTA, LTDTA and TDTA for these small and large-sized firms. As can be seen in Figure 1, short term debts are more than long term debts on average in both groups. But the weight of short term debts in total debts is more in small firms than in large firms.

Results of the analysis for these small and large-sized firm groups are summarized and interpreted below. Firstly, findings of leverage determinants for small firms are provided. Profitability is negatively associated with all three leverage ratios at the 1 percent significance level for small firms, which shows that small firms with more profits borrow less. Small firms' growth $(\triangle \mathrm{LNTA})$ is positively associated with long-term debt ratio at the 1 percent significance level, which is an indication of the fact that growing small firms can and do use long-term debt finance. These results on profitability and growth support the pecking order theory.

On the other hand, there is a positive relation between industry median leverage and all three leverage measures at the 1 percent significance level for small firms, which prove that small firms try to approach their indebtedness to their sector's average debt ratio. Tangibility has a positive association with long-term indebtedness at the 1 percent significance level for small firms, i.e. small firms that have more tangible assets can borrow for longer terms. These findings on industry median leverage and tangibility are in accordance with the predictions of the trade off theory.

As a result, one can conclude that small firms in Turkey firstly use their profits for expansion, take into account their sector's indebtedness rate when utilizing debt finance in both short and long maturities, and can borrow on longer terms, if they are high growth firms and have tangible assets.

Secondly, analysis results for variables which have a significant association with leverage measures of large-sized firms are presented and explained below. The coefficient of profitability is negative and significant at the 1 percent level for short-term and total debt ratios and at the 5 percent level for long-term debt ratio for large firms. This outcome proves that large firms with more profits also borrow less. This finding on profitability is in favor of the pecking order theory.

There is a positive and significant relationship between tangibility and long-term and total debt measures at the 1 percent level. This result demonstrates that large firms with tangible assets can and do also borrow on long-term basis by pledging their tangible assets. Size affects all three leverage measures positively and at the 1 percent significance level. This outcome suggests that size is treated as a proxy for safety and therefore large-sized firms can borrow more on both short and long-term basis. Our finding on size is also consistent with the results reached by Gönenç (2003), Sayılgan et al. (2006), Demirhan (2009), Yıldız et al. (2009), Bayrakdaroglu (2013) and Köksal et al. (2013).

Expected inflation affects all leverage measures positively and significantly. This relation is significant at the 1 percent level for long-term and total leverage ratios and at the 5 percent level for short-term leverage ratio. This result indicates that when future inflation is predicted to be high, large firms borrow more on all maturities. Growth (MVA/BVA) negatively and significantly affects short-term debt ratio of large firms at the 5 percent level, which shows that large growth firms decrease their short-term indebtedness in order to decrease risk of losing value in case of financial distress. There is a positive and significant association between industryMedian leverage and short-term and total debt ratios at the 1 percent level. This finding shows that large firms also try to approximate their leverage ratios to their sectors' debt ratios. All these findings on tangibility, size, expected inflation, growth and industry median leverage are in favor of the trade off theory. 
Table 4: Determinants of Leverage: Panel Data Estimation results based on Fixed Effects (FE) Models

\begin{tabular}{|c|c|c|c|c|c|}
\hline & STDTA & & LTDTA & & TDTA \\
\hline \multirow[t]{2}{*}{ NOP/TA } & $-0.19 * * *$ & & $-0.09 * * *$ & & $-0.275^{* * *}$ \\
\hline & $(-5.15)$ & & $(-3.58)$ & & $(-7.40)$ \\
\hline \multirow[t]{2}{*}{ NFA/TA } & -0.03 & & $0.09 * * *$ & & $0.061 *$ \\
\hline & $(0.97)$ & & $(4.75)$ & & (2.1) \\
\hline \multirow[t]{2}{*}{ LNTA } & 0 & & 0 & & -0.001 \\
\hline & $(-1.14)$ & & $(-1.25)$ & & $(-0.32)$ \\
\hline \multirow[t]{2}{*}{$\Delta$ LNTA } & -0.02 & & 0.01 & & -0.017 \\
\hline & $(-1.85)$ & & $(-0.77)$ & & $(-1.34)$ \\
\hline \multirow[t]{2}{*}{ Dep/TA } & 0.01 & & 0 & & 0.01 \\
\hline & $(1.21)$ & & $(-0.53)$ & & $(0.86)$ \\
\hline \multirow[t]{2}{*}{ oNOP/TA } & 0.11 & & 0 & & 0.11 \\
\hline & $(1.4)$ & & $(-0.04)$ & & $(1.36)$ \\
\hline \multirow[t]{2}{*}{ Explnf } & 0 & & 0 & & 0 \\
\hline & $(1.31)$ & & $(0.14)$ & & $(1.21)$ \\
\hline \multirow[t]{2}{*}{ GDPGr } & 0 & & 0 & & -0.001 \\
\hline & $(-0.53)$ & & $(-0.27)$ & & $(-0.70)$ \\
\hline \multirow[t]{2}{*}{ MVA/BVA } & $0.01 * * *$ & & 0 & & $0.007 * * *$ \\
\hline & (3.32) & & $(0.94)$ & & $(2.68)$ \\
\hline \multirow[t]{2}{*}{ IndMed } & $0.63 * * *$ & & 0.1 & & $0.729 * * *$ \\
\hline & (6.88) & & (1.66) & & (7.89) \\
\hline \multirow[t]{7}{*}{ Cons } & 0.12 & & -0.01 & & 0.113 \\
\hline & $(1.72)$ & & $(-0.14)$ & & $(1.61)$ \\
\hline & $F(10,3503)=13.23$ & & $F(10,3263)=8.1$ & & $F(10,3263)=19.01$ \\
\hline & Prob $>F=0$ & & Prob $>F=0$ & & Prob $>F=0$ \\
\hline & $\mathrm{R}-\mathrm{sqr}=0.075$ & & $R-s q r=0.069$ & & $\mathrm{R}-\mathrm{sqr}=0.055$ \\
\hline & Num Obs = & 3512 & Num Obs & $=3512$ & Num Obs $=3512$ \\
\hline & Num Grps = 239 & & Num Grps = 239 & & Num Grps = 239 \\
\hline
\end{tabular}

${ }^{*} p<0.05,{ }^{* *} p<0.01,{ }^{* * *} p<0.001, t$-values are in the parenthesis

Thus, it can be proposed that large firms use their profits first for investments, borrow more in all maturities if they are relatively large and if they predict inflation to increase, borrow on long-term if they have tangible assets, and try to approximate their especially short-term and total indebtedness to their sector's average debt ratios. In addition to the fact that small firms cannot benefit from their limited size as collateral for borrowing, there are two differences between small and large sized firms: Small growing firms borrow more on long-term and large firms increase their indebtedness in all maturities, if expected inflation is high. Based on these outcomes, we can conclude that the trade off theory explains financing behavior of large-sized firms better than the pecking order theory. 
Table 5: Determinants of Leverage: Panel Data Estimation Results based on Fixed Effects (FE) Models for Small and Large Firms

\begin{tabular}{|c|c|c|c|c|c|c|}
\hline & STDTA & & LTDTA & & TDTA & \\
\hline & small & large & small & large & small & large \\
\hline NOP/TA & $-2.14 * * *$ & $-0.196 * * *$ & $-0.087 * * *$ & $-0.085^{*}$ & $-.299 * * *$ & $-.281 * * *$ \\
\hline & $(-4.69)$ & $(-5.71)$ & $(-3.31)$ & $(-2.52)$ & $(-6.52)$ & $(-6.41)$ \\
\hline NFA/TA & -0.0738 & -0.0282 & $0.081 * * *$ & $0.131 * * *$ & 0.016 & $0.102^{* * *}$ \\
\hline & $(-1.76)$ & $(-0.99)$ & (3.39) & $(4.66)$ & $(0.37)$ & $(2.81)$ \\
\hline LNTA & -0.0043 & $0.0226 * * *$ & 0.0015 & $0.0542 * * *$ & -0.006 & $0.075 * * *$ \\
\hline & $(-1.02)$ & (3.5) & $(0.62)$ & (8.7) & $(-1.53)$ & $(8.8)$ \\
\hline$\Delta$ LNTA & -0.022 & 0.0099 & $0.027 * *$ & 0.011 & 0.006 & 0.018 \\
\hline & $(-1.27)$ & (1.13) & $(2.70)$ & (1.21) & $(0.33)$ & (1.58) \\
\hline Dep/TA & 0.0361 & -0.175 & 0.023 & $-0.068)$ & 0.019 & -0.273 \\
\hline & $(0.26)$ & $(-1.35)$ & $(0.31)$ & $(-0.53)$ & $(0.13)$ & $(-1.65)$ \\
\hline бNOP/TA & 0.0549 & 0.106 & -0.068 & 0.035 & 0.011 & 0.135 \\
\hline & (0.59) & (1.26) & $(-1.30)$ & $(0.42)$ & $(0.11)$ & (1.25) \\
\hline Explnf & 0.0001 & $0.0010^{*}$ & 0.0000 & $0.0019 * * *$ & 0 & $0.003 * * *$ \\
\hline & $(0.48)$ & $(2.32)$ & $(0.20)$ & (5.51) & $(0.5)$ & (5.16) \\
\hline GDPGr & -0.00125 & 0.0001 & 0.0004 & 0.000 & -0.001 & 0 \\
\hline & $(-1.21)$ & $(0.23)$ & (0.89) & (0.05) & $(-0.52)$ & $(-0.57)$ \\
\hline MVA/BVA & -0.0002 & $-0.0060 *$ & -0.0002 & 0.0016 & 0 & -0.004 \\
\hline & $(-0.09)$ & $(-2.02)$ & $(-0.16)$ & $(0.56)$ & $(-0.07)$ & $(-1.07)$ \\
\hline IndMed & $0.442 * *$ & $0.438 * *$ & $0.81 * *$ & 0.372 & $0.535^{* * *}$ & $0.399 * * *$ \\
\hline & $(2.84)$ & (3.1) & $(2.84)$ & (1.89) & $(4.43)$ & $(3.6)$ \\
\hline Cons & $0.218^{* * *}$ & $-0.361^{* *}$ & -0.007 & $-1.07 * * *$ & $0.227 * * *$ & $1.416^{* * *}$ \\
\hline & (3.24) & $(-2.73)$ & $(-0.17)$ & $(-8.23)$ & (3.32) & $(-8.23)$ \\
\hline$r 2$ & 0.069 & 0.083 & 0.055 & 0.119 & 0.09 & 0.184 \\
\hline$N$ & 1003 & 1280 & 1003 & 1280 & 1003 & 1280 \\
\hline
\end{tabular}

${ }^{*} p<0.05, * * p<0.01, * * * p<0.001, t$-values are in the parenthesis 


\section{Figure 1: Average Leverage Ratios of Small and Large Firms}

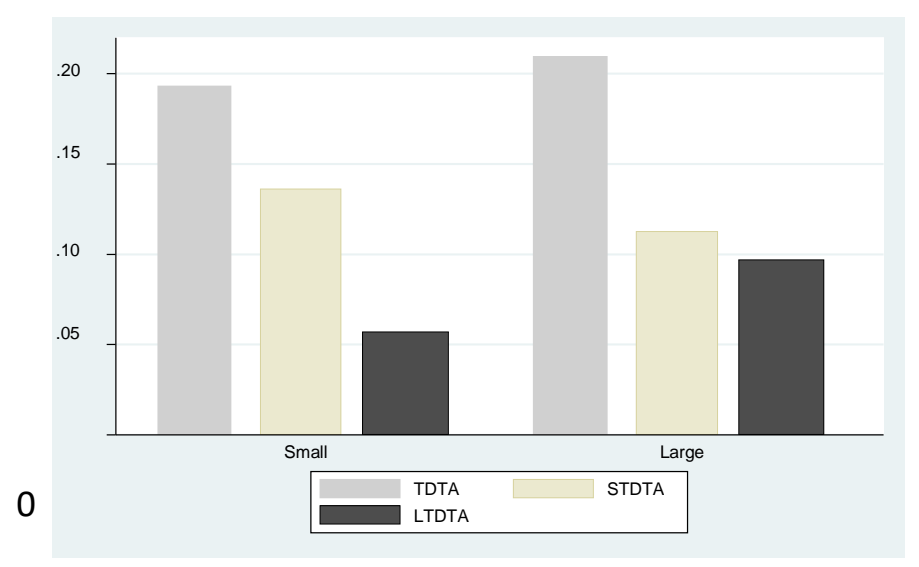

Turkey had a very severe financial crisis at the end of 2000 and at the beginning of 2001. In order to test whether there is any difference in factors and their signs affecting capital structures of Turkish listed companies, we divided our data set into two sub groups, 1988 to 2001 and 2002 to 2013, and repeated our analysis. Analysis results are given in Table 6. As can be seen in Figure 2 , all average debt measures have increased after 2001. However, as long term debts ratio has increased more than short term debts ratio, weight of long term debts has increased in total indebtedness after 2001.

Analysis results about the factors affecting firm leverage before 2002 are told below: There is a negative and significant relation at the 1 percent level between profitability and all three leverage ratios, which shows that firms had been using their internally generated profits first for investments and therefore borrowing less, if profits were high before 2002. We also detected a positive and significant relation between business risk and all three debt ratios at the 1 percent level, which reveals that risky firms had been closing their financing gap with debt capital before 2002. This outcome is consistent with the result of Korkmaz et al. (2007). Growth ( $\triangle$ LNTA) affected long-term indebtedness of firms positively and significantly at the 1 percent level, which shows that growing companies financed their funding needs with debt capital before 2002. There is a negative and significant relation between GDP growth rate and short-term leverage at the 5 percent level, which indicates that companies tend to decrease their short-term indebtedness during economic growth periods since they use their internally generated funds or borrow on long-term in good economic prospects. Two studies conducted on Turkish firms recently also found the same association between GDP growth rate and leverage, namely Bayrakdaroğlu et al. (2013) and Köksal et al. (2013). All these findings on profitability, risk, growth, and GDP growth rate are in line with the pecking order theory.

A positive and significant relation at 1 percent level between tangibility and long-term and total debt measures was identified in the analysis. This indicates that firms could have been borrowing on long-term if they had tangible assets before 2002 . Lastly, there is a positive and significant association at the 1 percent level between industry median leverage and long-term and total debt ratios. This finding shows that companies had been trying to approximate their long-term debt ratios to their sectors' leverage ratios before 2002. These results on tangibility and industry median leverage are in line with the predictions of the trade off theory. As most of the explanatory variables had sings in accordance with the pecking order theory, one can conclude that firms had been following the pecking order theory in forming their capital structures before 2002 in Turkey.

When we look at analysis' results for the factors affecting capital structure choices of firms for the period 2002 - 2013, we can draw the following conclusions: There is a negative and significant relationship at the 1 percent level between profitability and all three leverage ratios, which shows that firms have been still using their internally generated profits first for investments and therefore borrowing less if profits are high. Risk positively and significantly affects long-term debt ratio at the 5 percent level, which indicates that high risk firms borrow more on long-term. There is a positive and significant relation between growth (MVA/BVA) and short-term and total leverage ratios at the 1 percent level, which indicates that growth companies can increase their short-term and total indebtedness in the period after 2001. These findings on profitability, risk and growth supports the pecking order theory. 
Table 6: Determinants of Leverage: Panel Data Estimation Results based on Fixed Effects (FE) Models for Two Periods, before 2002 and after 2002

\begin{tabular}{|c|c|c|c|c|c|c|}
\hline & \multicolumn{2}{|l|}{ STDTA } & \multicolumn{2}{|l|}{ LTDTA } & \multicolumn{2}{|l|}{ TDTA } \\
\hline & $<=2001$ & $>=2002$ & $<=2001$ & $>=2002$ & $<=2001$ & $>=2002$ \\
\hline \multirow[t]{2}{*}{ NOPTA } & $-0.509 * * *$ & $-0.219 * * *$ & $-0.248 * * *$ & $-0.166 * * *$ & $-0.748 * * *$ & $-0.376 * * *$ \\
\hline & $(0.04)$ & $(0.06)$ & $(0.03)$ & $(0.03)$ & $(0.05)$ & $(0.05)$ \\
\hline \multirow[t]{2}{*}{ NFA/TA } & -0.009 & 0.001 & $0.211 * * *$ & 0.034 & $0.209 * * *$ & 0.009 \\
\hline & (0.04) & $(0.04)$ & $(0.03)$ & $(0.02)$ & $(0.05)$ & (0.03) \\
\hline \multirow[t]{2}{*}{ LNTA } & -0.001 & 0.010 & 0.004 & $0.039 * * *$ & -0.006 & $0.062 * * *$ \\
\hline & $(0.00)$ & $(0.01)$ & $(0.00)$ & $(0.01)$ & $(0.00)$ & $(0.01)$ \\
\hline \multirow[t]{2}{*}{$\triangle \mathrm{LNTA}$} & -0.024 & -0.017 & $0.035^{* *}$ & -0.004 & 0.021 & $-0.032 *$ \\
\hline & $(0.01)$ & $(0.02)$ & $(0.01)$ & $(0.01)$ & $(0.02)$ & $(0.01)$ \\
\hline \multirow[t]{2}{*}{ Dep/TA } & -0.073 & 0.012 & -0.075 & -0.002 & -0.188 & 0.009 \\
\hline & $(0.11)$ & $(0.01)$ & $(0.08)$ & $(0.01)$ & $(0.15)$ & $(0.01)$ \\
\hline \multirow[t]{2}{*}{ бNOP/TA } & $0.790 * * *$ & -0.071 & $0.270 * * *$ & $0.163^{*}$ & $1.089 * * *$ & 0.080 \\
\hline & $(0.08)$ & $(0.13)$ & $(0.05)$ & $(0.08)$ & $(0.10)$ & $(0.10)$ \\
\hline \multirow[t]{2}{*}{ Explnf } & -0.000 & $0.004 * *$ & 0.000 & $0.004 * * *$ & 0.000 & $0.008 * * *$ \\
\hline & $(0.00)$ & $(0.00)$ & $(0.00)$ & $(0.00)$ & $(0.00)$ & $(0.00)$ \\
\hline \multirow[t]{2}{*}{ GDPGr } & $-0.002 *$ & 0.000 & -0.001 & 0.000 & -0.002 & -0.000 \\
\hline & $(0.00)$ & $(0.00)$ & $(0.00)$ & $(0.00)$ & $(0.00)$ & $(0.00)$ \\
\hline \multirow[t]{2}{*}{ MVA/BVA } & 0.002 & $0.033^{* * *}$ & 0.002 & -0.003 & 0.004 & $0.033^{* * *}$ \\
\hline & $(0.00)$ & $(0.01)$ & $(0.00)$ & $(0.00)$ & $(0.00)$ & $(0.00)$ \\
\hline \multirow[t]{2}{*}{ IndMed } & 0.214 & $1.256^{* * *}$ & $1.115^{* * *}$ & $0.723^{* *}$ & $0.619^{* * *}$ & $0.515^{* * *}$ \\
\hline & (0.15) & $(0.27)$ & $(0.31)$ & $(0.23)$ & $(0.14)$ & $(0.13)$ \\
\hline \multirow[t]{2}{*}{ Cons } & $0.203^{* * *}$ & -0.203 & $-0.084 *$ & $-0.710 * * *$ & $0.137^{*}$ & $-1.119 * * *$ \\
\hline & (0.05) & $(0.23)$ & $(0.04)$ & $(0.13)$ & $(0.07)$ & $(0.18)$ \\
\hline $\mathrm{r} 2$ & 0.24 & 0.05 & 0.15 & 0.04 & 0.28 & 0.11 \\
\hline$N$ & 1151 & 2361 & 1151 & 2361 & 1151 & 2361 \\
\hline
\end{tabular}

${ }^{*} p<0.05,{ }^{* *} p<0.01,{ }^{* * *} p<0.001$, std errors are in the parenthesis 
Figure 2: Average Leverage Ratios before 2000 and after 2001

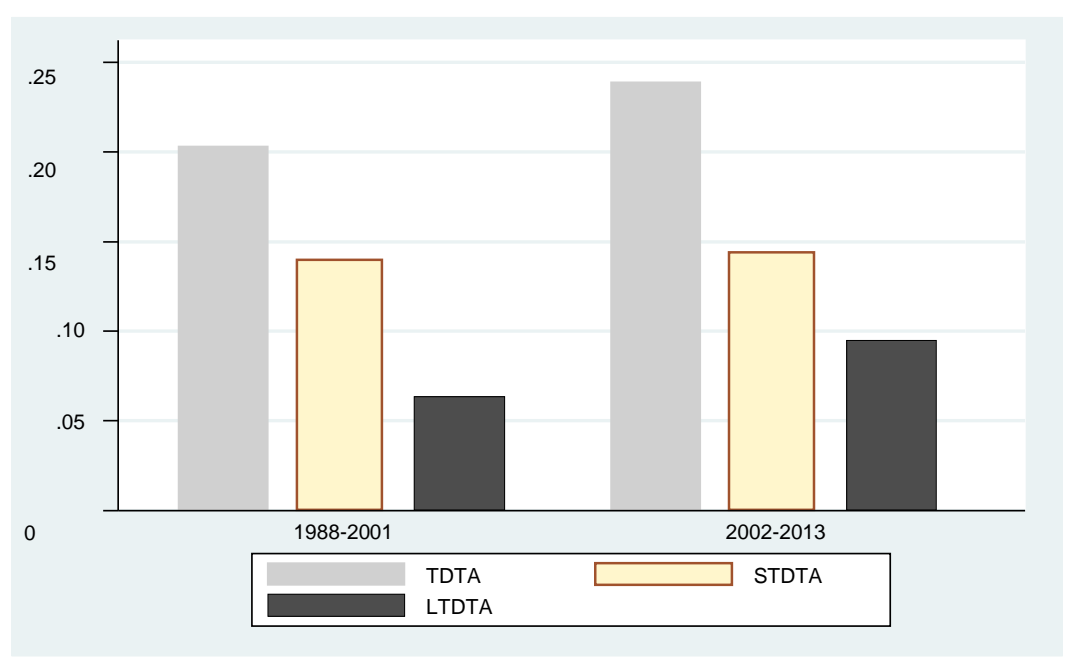

We detected a positive and significant relation between size and long-term and total leverage ratios at the 1 percent level, which indicates that large-sized companies are viewed as safer and therefore they can borrow more accordingly. The other growth measure ( $\triangle \mathrm{LNTA}$ ) negatively and significantly affects total debt ratio at the 5 percent level. This outcome indicates that firms finance their investments to assets from equity sources and therefore their indebtedness decrease after 2001. There is a positive and significant relation between expected inflation and all three debt ratios at the 1 percent level, which shows that firms have been increasing their indebtedness in all maturities after 2001 if expected inflation is high. This is because high expected inflation decreases present values of future interest payments. Lastly, there is a positive and significant association between industry median leverage and all three debt measures at the 1 percent level, which shows that firms are still trying to approximate their debt ratios of all maturities to their sectors' debt ratios after 2001. These results on size, growth ( $\triangle$ LNTA), expected inflation and industry median leverage are in accordance with the predictions of the trade off theory. Based on these differing results on factors influencing capital structure choices of firms during the period including 2001 and the period after 2001, we can conclude that capital structure theory that explains capital structure choices of Turkish listed firms has changed. For the 1988 to 2001 period the pecking order theory seems to better account for the capital structure choices of firms. On the other hand, firms seem to follow the trade off theory in forming their capital structures more closely than the pecking order theory for the period $2002-2013$.

\section{CONCLUSION}

In this study, we analyze factors affecting capital structure choices of Turkish non-financial listed companies. Aside from most studies conducted in developed countries, we also included short-term financial leverage as a dependent variable because Turkish firms could borrow on short-term during most of the analysis period due to the unstable macroeconomic environment. As well as the analysis based on the whole data set, as a robustness check, we also divided our firms into three clusters based upon assets size and repeated the same analysis for small and large-sized firms. Besides, we split our analysis period into 1988 to 2001 and 2002 to 2013 and applied the same analysis for these two sub periods, in order to determine whether there is any difference in capital structure choices of Turkish firms before and after the 2000 and 2001 crisis.

Result of our general analysis that covered the whole period for all firms revealed that 4 factors, i.e. profitability, growth (MVA/BVA), industry median leverage and tangibility were effective in explaining the capital structure of Turkish firms. Profitability and growth had signs consistent with the prediction of the pecking order theory; on the other hand, industry median leverage and tangibility had signs in favor of the trade off theory. Therefore, this general analysis's result is inconclusive about the capital structure theory that Turkish firms take into account in forming their capital structures. 
Analysis results of small firms show that 4 factors, namely profitability, growth ( $\triangle$ LNTA), tangibility and industry median leverage have significant influence on leverage ratios of small firm. While profitability and growth's signs favor the pecking order theory, signs of tangibility and industry median leverage are in the direction predicted by the trade off theory.

Large-sized firms' regression results indicate that profitability, tangibility, size, expected inflation, growth (MVA/BVA) and industry median leverage have a significant association with indebtedness of large-sized firms. Except for the sign of the profitability, all the remaining 5 variables have signs in accordance with the predictions of the trade off theory. This outcome proves that large-sized firms follow the trade off theory in forming their capital structures.

Our regression results for 1988 to 2001 period show that profitability, risk, growth ( $\triangle$ LNTA), GDP growth rate, tangibility and industry median leverage have explanatory power on Turkish firms' leverage ratios. While tangibility and industry median leverage have signs in accordance with the trade off theory, the remaining 4 variables have signs that are the same as the prediction of the pecking order theory. Therefore, the pecking order theory seems to better explain capital structure choices of Turkish listed firms before 2002. Lastly, profitability, risk, growth (MVA/BVA), size, growth ( $\triangle$ LNTA), expected inflation and industry median leverage are found effective in explaining the capital structures of Turkish listed firms during the period from 2002 to 2013. Profitability, risk and growth (MVA/BVA) had signs in line with the pecking order theory. On the other hand, the remaining 4 variables' signs are in accordance with the trade off theory. This outcome may be an indication of the fact that Turkish listed firms more closely follow the trade off theory in forming their capital structures since 2002.

\section{REFERENCES}

Acaravcı, S. K. (2014). The determinants of capital structure: Evidence from the Turkish manufacturing sector. International Journal of Economics and Financial Issues, 5(1), pp.158-171.

Asterious, D. (2006). Applied econometrics: A modern approach using Eviews and Microfit. Palgrave Macmillan.

Bayrakdaroglu, A., Ege, I., Yazici, N. (2013). A panel data analysis of capital structure determinants: empirical results from Turkish capital market. International Journal of Economics and Finance, 5(4), pp.131-140.

Borsa Istanbul Daily Bulletin (online). (December 31, 2014). Available at: http://borsaistanbul.com/en/data/data/equity-market-data/bulletindata.[Accesed in April 2015].

Brealey, R. A., Myers, S. C., Marcus, A. J. (2009). Fundamentals of corporate finance, Sixth Edition, McGraw-Hill.

Bradley, M., Jarrell, G. A., Kim, E. (1984). On the existence of an optimal capital structure: theory and evidence. The Journal of Finance, 39(3), pp.857-878.

Capital Markets Board of Turkey, Monthly Statistics Bulletin. (December 2014). Available at: http://www.spk.gov.tr/apps/aylikbulten/index.aspx?submenuheader=-1. [Accesed in May 2015].

Chen, D. H., Chen, C. D., Chen, J., Huang, Y. F. (2013). Panel data analyses of the pecking order theory and the market timing theory of capital structure in Taiwan. International Review of Economics \& Finance, 27, pp.1-13.

Demirhan, D. (2009). Sermaye yapisini etkileyen firmaya özgü faktörlerin analizi: IMKB hizmet firmalari uzerine bir uygulama. Ege Academic Review,9(2), pp.677-697.

Fischer, E. O., Heinkel, R., Zechner, J. (1989). Dynamic capital structure choice: Theory and tests. The Journal of Finance, 44(1), pp.19-40.

Frank, M. Z., Goyal, V. K. (2003). Testing the pecking order theory of capital structure. Journal of Financial Economics, 67(2), pp.217-248.

Frank, M. Z., Goyal, V. K. (2007). Trade-off and pecking order theories of debt. Available at: http://papers.ssrn.com/sol3/papers.cfm?abstract_id=670543. [Accesed in February 2015].

Frank, M. Z., Goyal, V. K. (2009). Capital structure decisions: which factors are reliably important?. Financial Management, 38(1), pp.1-37.

Frydenberg, S. (2004). Determinants of corporate capital structure of Norwegian manufacturing firms. Available at: http://papers.ssrn.com/sol3/papers.cfm?abstract_id=556634. [Accesed in February 2015].

Gönenç, H. (2003). Capital structure decisions under micro institutional settings: the case of Turkey. Journal of Emerging Market Finance, 2(1), pp.57-82.

Gülşen, A. Z., Ülkütaş, Ö. (2012). Sermaye yapisinin belirlenmesinde finansman hiyerarşisi teorisi ve ödünleşme teorisi: iMKB sanayi endeksinde yer alan firmalar üzerine bir uygulama. Uluslararası Yönetim İktisat ve İşletme Dergisi, 8(15), pp.49-59. 
Harris, M., Raviv, A. (1991). The theory of capital structure. The Journal of Finance, 46(1), pp.297-355.

Hausman, J. (1978). Specification tests in econometrics. Econometrica, 46, pp.1251-1271.

Ho, O. C. (2004). Determinants of foreign direct investment in China: a sectoral analysis. Department of Economics, University of Western Australia.Available at: http://www.web.uwa.edu.au/_data/assets/pdf_file/0019/102556/04_18_Ho.pdf. [Accesed in April 2015].

Korajczyk, R. A., Levy, A. (2003). Capital structure choice: macroeconomic conditions and financial constraints. Journal of Financial Economics, 68(1), pp.75-109.

Korkmaz, T., Albayrak, A. S., Karataş, A. (2007). Hisse senetleri iMKB'de işlem gören KOBi'lerin sermaye yapisinin incelenmesi: 1997-2004 dönemi. Iktisat Isletme ve Finans, 22(253), pp.79-96.

Köksal, B., Orman, C., Oduncu, A. (2013). Determinants of capital structure: evidence from a major emerging market economy. Working Paper. Available at: http://ssrn.com/abstract=2212648. [Accesed in March 2015].

Kraus, A., Litzenberger, R. H. (1973). A state-preference model of optimal financial leverage. The Journal of Finance, 28(4), pp.911-922.

MacKie-Mason, J. K. (1990). Do taxes affect corporate financing decisions?. The Journal of Finance, 45(5), pp.1471-1493.

Modigliani, F., Miller, M. H. (1958). The cost of capital, corporation finance and the theory of investment. The American Economic Review, 48(3), pp.261-297.

Modigliani, F., Miller, M. H. (1963). Corporate income taxes and the cost of capital: a correction. The American Economic Review, 53(3), pp.433443.

Myers, S. C. (1984). The capital structure puzzle. The Journal of Finance, 39(3), pp.574-592.

Myers, S. C. (2001). Capital structure. Journal of Economic Perspectives, 15(2), pp.81-102.

Myers, S. C., Majluf, N. S. (1984). Corporate financing and investment decisions when firms have information that investors do not have. Journal of Financial Economics, 13(2), pp.187-221.

Myers, S. C., Read Jr, J. A. (2012). Real options, taxes and financial leverage (No. w18148). National Bureau of Economic Research. Available at: http://www.nber.org/papers/w18148.pdf. [Accesed in June 2015].

Sayılgan, G., Karabacak, H., Küçükkocaoğlu, G. (2006). The firm-specific determinants of corporate capital structure: evidence from Turkish panel data. Investment Management and Financial Innovations, 3(3), pp.125-139.

Schoubben, F., Van Hulle, C. (2004). The determinants of leverage; differences between quoted and non-quoted firms. DTEW Research Report, 0450, pp.1-32.

Shyam-Sunder, L., Myers, S. C. (1999). Testing static tradeoff against pecking order models of capital structure. Journal of Financial Economics, 51(2), pp.219-244.

Titman, S., Wessels, R. (1988). The determinants of capital structure choice. The Journal of Finance, 43(1), pp.1-19.

Tong, G., Green, C. J. (2005). Pecking order or trade-off hypothesis? evidence on the capital structure of Chinese companies. Applied Economics,37(19), pp.2179-2189.

World Federation of Exchanges Website. http://www.world-exchanges.org/statistics/monthly-reports, April 18, 2015. [Accesed in January 2015].

Yıldız, M. E., Yalama, A., Sevil, G. (2009). Sermaye yapisi teorilerinin geçerliliğinin test edilmesi: panel veri analizi kullanilarak iMKB-imalat sektörü üzerinde ampirik bir uygulama. Iktisat Isletme ve Finans, 24(278), pp.25-45.

The World Bank Website. http://data.worldbank.org/indicator/NY.GDP.MKTP.KD.ZG. [Accesed in January 2015].

Turkish Statistical Institute Website. http://www.tuik.gov.tr/PreTablo.do?alt_id=1014. [Accesed in January 2015].

Central Bank of Republic of the Turkey, Electronic Data Delivery System. http://evds.tcmb.gov.tr/. [Accesed in January 2015]. 